International Journal of Instruction e-ISSN: 1308-1470 • www.e-iji.net

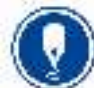

April 2021 • Vol.14, No.2

p-ISSN: 1694-609X

pp. $197-216$

Article submission code: 20200229111114

Received: 29/02/2020

Revision: 05/09/2020
Accepted: 29/09/2020

OnlineFirst: 16/01/2021

\title{
Effect of Child Literature Based Integrative Instructional Program on Promoting 7th Graders Writing Skills: An Empirical Study
}

\section{Sara El-Freihat}

Dr., Al-Balqa' Applied University, Jordan, sara.freihat@ bau.edu.jo

\author{
Abeer Al-Shbeil \\ Dr., Al-Balqa’ Applied University, Jordan, dr.abeer.sh@bau.edu.jo
}

The study aimed to investigate the effect of child literature based integrative instructional program on promoting $7^{\text {th }}$ graders writing skills at Irbid governorate in Jordan. The sample of the study totaled (87) male and female students selected purposefully. These were randomly assigned into four groups, two experimental groups, the first was males $(\mathrm{N}=24)$ and the second was females $(\mathrm{N}=22)$, and was taught using integrative approach, and two control groups, the first was males (19) and the second was females (22) was taught using the conventional method. To examine the effectiveness of the child literature based integrative instruction, a semi-experimental pre-posttest design was used. For data analysis, means scores, standard deviation and multiple one-way ANOVA were calculated. The results of the study showed statistically significant differences in the means scores of writing skill posttest, in favor of the experimental group. The study found statistically significant differences in the effect of using the integrative method in teaching children literature to develop writhing skill among seventh grade students due to gender, in favor of females. In light of the results some recommendations were provided.

Keywords: integrative instructional method, literature, writing skills, Irbid governorate, Jordan

\section{INTRODUCTION}

There is no doubt that languages are one of the greatest achievements of mankind; since it provides a tool for communication with others by giving the individuals the means for expressing his feelings and ideas. It is a tool for communicating human experiences from one generation to another. As one of the most important language skills, writing has been and still an important sub-skill of language proficiency; it is transmitting one's experience to others by relying on symbols represented by letters and punctuation marks so as the reader can obtain the ideas provided in the written text (Barakat, 2006). Emphasizing this fact, Javed, Juan and Nazli (2013) have stressed the importance of

Citation: El-Freihat, S., \& Al-Shbeil, A. (2021). Effect of Child Literature Based Integrative Instructional Program on Promoting 7th Graders Writing Skills: An Empirical Study. International Journal of Instruction, 14(2), 197-216. https://doi.org/10.29333/iji.2021.14212a 
language as an effective communication tool for feelings and ideas used by people from different backgrounds to mirror their inner feelings and emotions to others.

Bassal (2005) postulate that language skills occupy a vital role in the daily interactions among individuals. As one of language skills, writing is of great significance since it enables people to convoy their feelings to other in a clear way; making it easier to comprehend what other people want to say. Attempting to describe writing as a process, one can argue that it is one of the main accomplishments humans have reached in their quest for developing their daily life. Without writing, it is almost impossible that humans have achieved their development seen nowadays as writing is the instrument used of past generations to transfer what they have gained of knowledge and technological development to the future generations. It can be said, then, that without writing; past generations would not be able to communicate their heritage to the new one's as written history, not oral history, is the one used for sharing experiences with people from different civilizations and generations (Erdogan, 2013).

For Kellogg (2008), writing is a basic language skill and it is the most difficult to master as learners find it hard to learn the writing skills. For native speakers in different languages, writing sub-skills need attention by teachers who recognize the hardships learners face while attempting to master writing as a process. Furthermore, what makes writing a challenge for learners is that it relies on finding the accurate words, sentences able to reflect what an individual is feeling. Therefore, to be a competent writer dictates the need for having a rich vocabulary repertoire so as one can express his ideas and emotions, two things that are not material in nature and need higher order thinking skills.

As writing a difficult task, it requires using various cognitive skills such as previous knowledge gained from the writer's interaction with many forms of text; affective one's including convoying the emotional state of the writer by employing symbols and punctuation marks; social relating to the nature of the writer interactions with the surrounding environment. In the writing process, the writer must coordinate between these different aspects to give the reader a comprehensive and thorough description of what he wishes to give the readers of the written text (Graham, Berninger \& Abbott, 2012). In the same line of research, Rababeh and Abu Jamous (2012) believe that mastering writing assumes that the writer can manipulate the other language skills (reading, speaking, listening) by creating a harmony between them to present a cohesive text.

Realizing the importance of writing, The Jordanian Ministry of Education (2006) stated that features must work on selecting the most effective instructional strategies to teach students writing. It also acknowledge the importance of this language skill by calling curricula developers to design cohesive curricula in Arabic so as students can benefit from the writing activities presented in the different grade levels. It state the following: The outcomes of writing in the different grade levels is to communicate information and ideas clearly and correctly for specific purposes and audiences in a variety of advance authentic context, and it is expected that students will: First, gather information and ideas from print and electronic sources to write and organize in some advanced authentic contexts. Second, write series of paragraphs for some advanced authentic 
purposes and audiences, such as ads, short essays, reports, news items, short stories, rhymes, and short dialogues (p. 58).

Finding effective instructional strategies to teach writing skill has been a major concern for educational scholars and teachers. Some of these strategies included the use of different learning theories; the dependence on new technologies such as the internet and smartphone. One of these strategies is integrative approach which is based on the concepts and assumptions of Dewey arguing that the whole life is integrative in nature; meaning that one element completes the other and each cannot be separated. In other words, there is a need to integrate such elements to make a whole. Researchers have benefited from these assumptions, especially in language teaching, which included the integration of different language skills while targeting the promotion of a specific subskill (Dahrouj, 2016).

Sakhelashvili (2016) supported such idea and called for using integrative approach as an effective teaching method in the different school subjects. It provides learners with the opportunity to interact with the different content areas in any given school subject while working on integrating them wholly. In this sense, teachers can work with students by synthesizing the various curriculum components in a cohesive structure while each component fulfills specific skills to reach a certain level of mastery.

The use of integrative dates back to more than two hundred years as it was presented by different language scholars during that time. It reappeared another time in the 1960's as a result of different research studies by Hilda Taba and other language scholars. In the 1980 's and as a result of the focus on developing higher order thinking skills, there was a new interest in using integrative approach in teaching language as language acquisition researchers claimed that language learning should be an integrative process as both teachers and students should develop an ideology and concrete conceptions in that to learn a language, you should master the four basic language skills (Muhammad, 2018). In the same vain, Murthy and Ram (2015) contended that the idea of integrative approach is not a new one in teaching first and second language, but the last developments in language acquisition theories have motivated scholars to focus more on such an approach as a means for helping students effectively master the four language skills concurrently.

Hilda Taba (cited in Aydin, Unver, Alan \& Saglam, 2017) was a pioneer in the use of integrative approach in language teaching and learning and called for teachers and students to employee such instructional design in the different academic contexts. In her integrative curricula she claimed that the following assumptions should be taken into consideration: Learning is a social process and this signifies the need for social interaction between teachers and students; learning is a linear process; the effective employment of social environments to promote learning among students; the need to develop modern curricula conforming to the advanced learning theories; considering language as a whole which means that teachers and students should take the language learning as a comprehensive integrated process needing much effort by both. 
Ibrahim and Al-Deleamy (2013) argued that integrative teaching strategy is one of the instructional programs used in teaching different languages as it based on a basic assumption that language skills can't be separated from each other and should be taught concurrently. In the same line, Djakaridja and Ismail (2016) postulate that integrative teaching in language learning and teaching is a philosophy in addition to being a method of giving students opportunities to learn different language skills at the same time. For Ryan, Glodji, Hobbs, Stragel and Williams (2015), integrative teaching is based on several tenets; the most important is to teach students a language based on their background knowledge, providing different reading experiences as being part of communication process which include in addition to reading, speaking, listening and writing; encouraging students to use their language skills in writing and composition; motivating students to use materials from the surrounding environment as a means of learning.

Teachers can adopt different forms of integrative approaches in teaching writing. For example, Jubran (2017) argued that the use of process - product approach can give students many invaluable chances to acquire both fluency and accuracy in the writing process. It can also use the strengths students have in writing a specific type of texts. Furthermore, the teacher can manipulate these two important features of language skills instruction so as both teachers and students are actively engaged in learning - teaching situation focusing on the idea that mastering writing requires an integrative interaction between the mental processes in the writing to produce a written text able to fulfill the requirements of excellent writing.

In the same vain, Alnassir (2011) called for an integrative view for teaching and learning language skill. As a language is an essence to find the suitable integration of learners' daily life activities, teachers must use what students have in their background repertoire to build learning activities conforming to the nature of language itself. Almosa (2003) further claims that teaching language skills does not fulfill the basic assumptions proposed by different learning theories which state that language cannot be taken separately and must be taught as a whole.

Therefore, this study attempted to identify the effect of integrative instructional method in teaching child literature on promoting $7^{\text {th }}$ graders writing skills at Irbid governorate in Jordan. Based on the researchers field experience, they noted that children literature is an effective tool to be employed using integrative approach in teaching students, especially in the early grade levels such as seventh grade targeted language skills as they are more willing to acquire such skills if integrative approach is effectively used by designing well organized learning experiences.

Various studies have been conducted to examine the effect of a variety of teaching method on writing. For example, In Saudi Arabia, Alnassir (2011) studied the effect of using integrated approach in teaching Arabic reading and writing skills among sixth grade students. A sample totaling (62) male students was selected and randomly assigned into two study groups. The first included (31) male students taught reading and writing skills using integrative approach and presented the experimental group, while the second was control $(\mathrm{N}=31)$ and was taught using the traditional teaching method. The 
posttest reading and writing skills scores indicated statistically significant differences between the experimental and control groups, in favor of the former. While Alnooh (2015) study examined the impact of using integrated approach to the teaching of writing skills among secondary students of English as a foreign language in Saudi Arabia. The study sample consisted (60) secondary level female students distributed into two equal groups, experimental and control group. For data collection a questionnaire and pre and posttest were used. The study revealed a positive impact of the integrated approach in improving writing performance, motivation and attitude towards writing in English. Abu Dahroj (2016) examined the effectiveness of an integrative approach based program in developing Arabic writing skills among basic grade students. The sample of the study totaled (31) third grade female students whom were exposed to an integrative approach based on instructional program. To verify the effect of the instruction program, Arabic writing skills pre-posttests were administrated to the students at the beginning and completion of the study. The study results found statistically significant differences between students' pre-posttest Arabic writing skills, in favor of posttest.

Abu Hamda and Al-Khawaldeh (2017) used a sample of (70) male and female third grade students to study the effectiveness of active learning on students reading and writing skills. The study concluded that there were statistically significant differences between the experimental group and control group in reading and writing as a whole and the sub-skills of these two language skills. Another study by Muradi (2018) attempted to identify the most prevalent challenges faced by teachers when teaching writing. A sample of (19) previous studies where found and content analyzed. The findings of the study showed that teaching Imla' (spelling) was the most significant challenge reported by teachers, followed by Insya (Composition) with high difficulty levels. The study concluded that writing is hard to teach since it contains different sub-skills meaning attentive focus by both students and their teachers. Bin Daymoon, Bin Sa'd and Ja'far (2018) studied the effect of using documentary films in teaching writing expressions skill. To achieve this objective, (83) students were randomly selected and assigned into two study groups. The first was experimental taught using documentary films and included (42) male and female students, while the second was control and was taught using the traditional instructional method. The results of the study indicated statistically significant differences in the mean scores of students writing expression posttest, in favor of the experimental group taught using documentary films.

By reviewing previous studies it can be concluded that the aim of some studies (e.g. Alnassir, 2011) was to reveal the effect of using integrated approach in teaching Arabic reading and writing skills among sixth grade students, while this study aims to investigate the effect of child literature based integrative instructional program on promoting writing skills among $7^{\text {th }}$ graders. Also, previous studies used various student samples for example Abu Dahroj (2016) used a sample of third grade female students and Alnooh (2015) used a sample of secondary level female students, while the current study used a sample of seventh graders. 


\section{Problem of the Study}

Language plays a vital role in communication, and this needs more attentions by researchers wishing to promote students' academic achievements in different school subjects. For this reason, educational scholars are called to find the most effective instructional strategies for language skills. Basically, writing as being found to be the most difficult language skill requiring more effort by teachers and students at the same time.

Different studies has reported that students writing skills are low, stressing the need to develop effective instructional method able to promote such language skill among students. For example Abu Dahroj (2016) indicated that students lack the necessary writing skills in Arabic and that dictates the need for designing effective teaching strategies able to promote such an important language skill.

In Jordan, Jubran (2017) found that college students are still unable to develop the needed writing skills. The author called for effective instructional strategies which can assist students master different language skills. He concluded by recommending Arabic language teachers to employ different language skills to teach one targeted skill in language. As such, this study is an attempt to answer the following questions:

- What is the effect of using an integrative method in teaching children's literature on the development of writing skill among seventh grade students?

- What is the effect of using the integrative method in teaching children literature to develop writhing skill at seven grad students due to gender?

\section{METHOD}

\section{Sample of the Study}

The study sample consist of the seventh grade students in the Directorate of Education in Irbid Governorate, because of their proximity to the work of the researchers, in order to allow them to follow the students closely, and make sure the application of the study properly.

The study sample was chosen purposefully, consisting of four sections, two experimental sections (males, $\mathrm{n}=24$ / females, $\mathrm{n}=22$ ) and two control sections (males, $\mathrm{n}=19$ / females, $\mathrm{n}=22$ ). Thus, the members of the control group studied the spelling content in an integrative method, while the members of the control group studied in the conventional way. The sample ranged in age between 13 and 14 years old $(M=13.2)$. Study Instruments:

\section{Spelling Achievement Test}

The test is designed to measure the achievement of the study sample, and was based on the following procedures: 
- The test was designed based on the spelling content of the book scheduled for the seventh grade students, and includes the following topics: middle Hamza, Adding "if" (?th) to adverbs, dual Alef, "L" of imperative and "F" added to it.

- Middle Hamza, was distributed based on the relative importance and sub-rules. Middle Hamza had (14) items, because it has sub-rules more than others, and the items were distributed as following:

a- Middle Hamza, address using (1-14) items.

b- Adding "if" (?th) to adverbs, address using (15-23) items.

c- Dual Alef, address using (24-32) items.

d- "An" (?n) for accusative and "La" for denial, joined or separated, address using (33-41) items.

e- $\quad$ "L" of imperative and "F" added to it, address using (42-50) items.

\section{Validity and Reliability}

To check the validity of the test, it was given to a number of experts in general curricula, Arabic language curricula and its teaching methods, Arabic language supervisors and a number of teachers, to give their opinions and observations about the test, in terms of language accuracy, the content of each individual item, clarity of items, and any observations they deem appropriate.

In the light of the experts' observations, paragraphs $(2,4,30,31,32,46)$ have been amended in terms of accuracy language, and the test in its final form consists of (50) items distributed on spelling issues.

To check the reliability of the test, the test was administrated to a pilot study selected out of the study sample consisting of (17) male students and (21) female students. The coherence consistency coefficient of the test with using K-R Richardstone equation 20 was (0.82). It is accepted to achieve the study purposes and calculating reliability using Test-Re Test method on a pilot study, which was (0.89), and this value is accepted to achieve the study purposes.

\section{Discrimination and difficulty Indicators of the Test}

To check discrimination and difficulty indicators of the test, the researcher administrated the achievement test to a sample of (20) students and then calculated difficulty coefficients which ranged between $(0.25-0.68)$ and discrimination coefficients which ranged between $(0.31-0.57)$ and these values are suitable for the purposes of the study. 
Table 1

Discrimination and difficulty Indicators of the Test

\begin{tabular}{lllllllll}
\hline No. & Diff. & Disc. & No. & Diff. & Disc. & No. & Diff. & Disc. \\
\hline 1 & 0.53 & 0.31 & 18 & 0.56 & 0.39 & 35 & 0.39 & 0.53 \\
\hline 2 & 0.41 & 0.51 & 19 & 0.58 & 0.44 & 36 & 0.53 & 0.38 \\
\hline 3 & 0.37 & 0.52 & 20 & 0.39 & 0.55 & 37 & 0.39 & 0.44 \\
\hline 4 & 0.68 & 0.39 & 21 & 0.49 & 0.35 & 38 & 0.28 & 0.36 \\
\hline 5 & 0.34 & 0.43 & 22 & 0.51 & 0.52 & 39 & 0.53 & 0.43 \\
\hline 6 & 0.49 & 0.6 & 23 & 0.41 & 0.53 & 40 & 0.34 & 0.42 \\
\hline 7 & 0.63 & 0.33 & 24 & 0.34 & 0.43 & 41 & 0.48 & 0.55 \\
\hline 8 & 0.25 & 0.36 & 25 & 0.49 & 0.34 & 42 & 0.47 & 0.48 \\
\hline 9 & 0.34 & 0.38 & 26 & 0.56 & 0.38 & 43 & 0.55 & 0.4 \\
\hline 10 & 0.39 & 0.41 & 27 & 0.51 & 0.55 & 44 & 0.42 & 0.39 \\
\hline 11 & 0.37 & 0.53 & 28 & 0.27 & 0.37 & 45 & 0.56 & 0.49 \\
\hline 12 & 0.75 & 0.46 & 29 & 0.49 & 0.49 & 46 & 0.54 & 0.4 \\
\hline 13 & 0.32 & 0.31 & 30 & 0.65 & 0.57 & 47 & 0.41 & 0.48 \\
\hline 14 & 0.46 & 0.37 & 31 & 0.72 & 0.37 & 48 & 0.51 & 0.49 \\
\hline 15 & 0.34 & 0.37 & 32 & 0.41 & 0.37 & 49 & 0.46 & 0.44 \\
\hline 16 & 0.41 & 0.4 & 33 & 0.41 & 0.46 & 50 & 0.58 & 0.55 \\
\hline 17 & 0.51 & 0.45 & 34 & 0.65 & 0.46 & & & \\
\hline
\end{tabular}

\section{Test Duration}

The test duration was determined by taking the average of the first five students who completed the test from the pilot study. The duration was approximately (50) minutes, then taking the average of the last five students, the duration was approximately (70) minutes, consequently the average duration adopted by the study samples was (60) minutes.

\section{Test Scoring}

The test was scored according to the standard scoring key, and two points was given to correct the answers, and a zero point for the wrong answer, so the highest score of the test was (100) score, and the test was eliminated in the case of answered wrongly or item has more than an answer or left unanswered.

\section{Groups Equivalence}

To check the equivalence of the experimental and control groups, a pre-test and calculation of means and standard deviation were administrated based on group and gender variable, as shown in Table (1). 
Table 1

Means and standard deviation of pre-spelling test based on group and gender variable

\begin{tabular}{lllll}
\hline Group & Gender & M & SD & No. \\
\hline \multirow{3}{*}{ Experimental } & Male & 40.0 & 12.65 & 24 \\
\cline { 2 - 5 } & Female & 44.91 & 11.29 & 22 \\
\cline { 2 - 5 } & Total & 42.35 & 12.14 & 46 \\
\hline \multirow{3}{*}{ Control } & Male & 44.58 & 9.16 & 19 \\
\cline { 2 - 5 } & Female & 41.68 & 10.27 & 22 \\
\cline { 2 - 5 } & Total & 43.02 & 9.76 & 41 \\
\hline \multirow{3}{*}{ Grand Total } & Male & 42.02 & 11.35 & 44 \\
\cline { 2 - 5 } & Female & 43.30 & 10.79 & 87 \\
\cline { 2 - 5 } & Total & 42.67 & 11.03 & \\
\hline
\end{tabular}

Two-way ANOVA analysis was used to show statistically significant differences between groups in the pre-test, as shown in Table (2).

Table 2

Two-Way ANOVA analysis for group and gender variables and their interaction in prespelling test

\begin{tabular}{llllll}
\hline Variance Source & Total Squares & dif & Total Squares Means & F Value & Sig. \\
\hline Group & 9.865 & 1 & 9.865 & 0.081 & 0.776 \\
\hline Gender & 21.857 & 1 & 21.857 & 0.180 & 0.673 \\
\hline Gender and Group & 329.021 & 1 & 329.02 & 2.708 & 0.104 \\
\hline Error & 10083.22 & 83 & 121.485 & & \\
\hline Total & 10455.33 & 86 & & & \\
\hline
\end{tabular}

Table (2) shows that there are no differences $(\alpha=0.05)$ due to the group, where $F$ value was $(0.081)$ with statistically significant $(0.776)$, and Table (2) also shows that there are no differences significance $(\alpha=0.05)$ due to gender, where $F$ value was $(0.180)$ and statistically significant $(0.673)$, and there are no differences $(\alpha=0.05)$ due to the group and gender, where F value was (2.708) with statistical significance (0.104), which indicates the equivalence of groups.

\section{Integrative Method Based-Activities and Drills}

- First: The concept of the integrative method: It is a set of procedures by which the teacher performs the lesson of literature, through organizing educational positions that allow students to learn one or more of the language skills taking into account aspects of integrated experience: cognitive, skills, and emotional aspects.

- Second: The objectives of activities and drills: Using activities and drills in an integrative way, allow to achieve learning outcomes among experimental group students, these include: Train students to spell accuracy by the integrative between language skills related to children's literature, and mastering students the targeted spelling and written skills, and theoretical knowledge related, and the high level of performance of students in writing and spelling, particular issues being in the current study. 
- Third: Learning Content: Includes five activities consisting of texts and short stories addressing specific spelling issues, these include: moderate Hamza, and adding "if" (?th) to adverbs, dual Alef, "L" of imperative and "F" added to it, and "An" (?n) for accusative and "La" for denial, joined or separated, .

- Four: Implementation activities mechanism: The measurement method was used to present the theoretical background related to the specific spelling issue, and then to present the activities and drills to the students in the form of groups and collectively based on the nature of the activity, through texts or paragraphs have been formulated to compose literature in a manner that takes into account the needs and experience of students, to allow this method for students to integrate with language skills and understanding of specific spelling issues. A number of instructional aids were used to suit with literary activities and literature texts, the most important include: whiteboard, voice recorder, cardboard, and presentations on the computer.

- Fifth: Evaluation methods: To check the effectiveness of the activities, the following types of evaluation were adopted:

a. Pre-Evaluation: By using the pre-test enabling the students to assess the spelling issues in the current study, which consists of (50) different items, included (multiple choice, fill blanket, yes / no questions).

b. Construction Evaluation: By implementing activities, quiz, observation, and drills.

c. Final Evaluation: By using the post-test, after the administrating of the study, to compare the results with the pre-test, to find out the improvement level of spelling among students.

- Sixth: The proposed literature activities was implemented from the beginning of the first semester of the academic year 2018/2019, totaling (14) classes, in average of three classes for each spelling issue, where the implementation began on March 2019, and ended on to May 2019.

- Seventh: Study administration: A male teacher holding B. A. degree in Arabic language and has 8 years of experience in teaching Arabic language, was chosen to teach the seventh grade male students in a school at Irbid the first Educational Directorate to implement the literature activities based on the integrative method on the experimental sample for male. A female teacher holding B.A degree in Arabic language and has 6 years of experience in teaching Arabic language, was chosen to teach the seventh grade female students in a school at Irbid the first Educational Directorate to implement the literature activities based on the integrative methods, where meeting with teachers was prepared to assess the objectives and instruments of the study, and literature activities based on the integrative method, were they were trained on how to implement the activities by the appropriate strategies and how to administrating the test, and answering all their inquiries and questions about the study procedures. 


\section{Validity of the Activities and Drills}

Literature activities and drills were given to a group of experts in Arabic language and its curricula, and asked them to express their opinion in terms of: linguistic accuracy, and the appropriate for the contents of spelling, clarity, and amendments were made according to their remarks, the most important include: the use of presentations as a means of displaying literary texts, the use of the word Activities instead of Activity, the use of the word mastery rather than comprehension, modify the sentence (a complete sentence) to (a complete meaningful sentence), where the amendments was carried out and final format of the training were developed.

\section{Procedures}

- Selecting study sample from the Directorate of Education in Irbid.

- Preparing the test and given it to experts to check its validity.

- Preparing integrative method based-literature activities, and presenting them to the experts.

- Accessing permission letters.

- Meeting with schools principals and teachers, to agree on the schedule of the study implementation.

- Training experimental group teachers on how teaching literature texts in an integrative methods.

- Administrating spelling test on the pilot study selected out the original sample from the Directorate of Education in Irbid, after two weeks the same test was administered a second time and correlation coefficients were calculated..

- Administrating spelling test on the experimental study sample the before administrating the study to verify of equivalence between groups.

- Administrating the proposed literature activities on the experimental group, and the conventional method on the control group, from the beginning of the first academic semester 2017/18.

- Administrating the test on the experimental and control group.

- Entering scores to the computer and conducting statistical analysis.

- Results and discussion.

\section{Study Design}

Semi-experimental design was used which consist of two equivalence groups, experimental group (males / females), control group (males / females), and Test-Retest. 


\section{Study Variables}

- Independent variable: It consists of the teaching method, include two levels: the conventional method, and the integrative method.

- Dependent variable: It consists of writing skills examined in the current study, include two levels: male and female.

- Statically Analysis: SPSS program was used to analyze the data, where the mean scores, standard deviation and one Way ANOVA were calculated to answer the first question, while mean scores, standard deviation, one Way ANOVA and Multiple One way ANOVA analysis were calculated to answer the second question.

\section{FINDINGS}

Results of the First question: What is the effect of using an integrative method in teaching children's literature on the development of writing skill among seventh grade students?

To answer the first question, means score and standard deviation of the writing skill were calculated, for each of the test domains based on the teaching method (conventional and integrative), as shown in Table (3).

Table 3

Means and standard deviation for writing test based on teaching method

\begin{tabular}{|c|c|c|c|c|c|}
\hline Domain & Writing Skill & Teaching Method & $\mathrm{M}$ & $\mathrm{SD}$ & No. \\
\hline \multirow{3}{*}{ 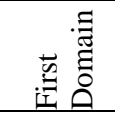 } & \multirow{3}{*}{ Middle Hamza } & Integrative & 20.48 & 5.34 & 46 \\
\hline & & Conventional & 15.37 & 5.66 & 41 \\
\hline & & Total & 18.07 & 6.03 & 86 \\
\hline \multirow{3}{*}{ 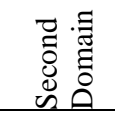 } & \multirow{3}{*}{$\begin{array}{l}\text { Adding "if" (?th) to } \\
\text { Adverbs }\end{array}$} & Integrative & 14.65 & 2.57 & 46 \\
\hline & & Conventional & 12.49 & 3.54 & 41 \\
\hline & & Total & 13.63 & 3.24 & 86 \\
\hline \multirow{3}{*}{ 己. } & \multirow{3}{*}{ Dual Alef } & Integrative & 15.0 & 2.56 & 46 \\
\hline & & Conventional & 12.39 & 3.17 & 41 \\
\hline & & Total & 13.77 & $3 . .5$ & 86 \\
\hline \multirow{3}{*}{ 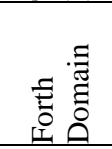 } & \multirow{3}{*}{$\begin{array}{l}\text { "An" (?n) for } \\
\text { Accusative and "La" } \\
\text { for Denial, Joined or } \\
\text { Separated }\end{array}$} & Integrative & 15.0 & 2.45 & 46 \\
\hline & & Conventional & 12.10 & 3.79 & 41 \\
\hline & & Total & 13.63 & 3.46 & 86 \\
\hline \multirow{3}{*}{ 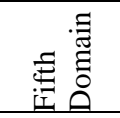 } & \multirow{3}{*}{$\begin{array}{l}\text { "L" of Imperative } \\
\text { and "F" Added to it }\end{array}$} & Integrative & 14.70 & 2.87 & 46 \\
\hline & & Conventional & 12.34 & 3.49 & 41 \\
\hline & & Total & 13.59 & 3.37 & 86 \\
\hline & \multirow{3}{*}{ Grand Total } & Integrative & 79.89 & 12.76 & 46 \\
\hline & & Conventional & 64.52 & 15.45 & 41 \\
\hline & & Total & 72.66 & 15.04 & 86 \\
\hline
\end{tabular}

Table (3) shows an apparent variance in the means score and standard deviation of the performance of the basic stage students in each sub-skill the total test skills and on the total writing test between the categories of variable teaching method (integrative, 
conventional), where the means score were high in favour of the integrative method for each skill.

Multiple one-way ANOVA analysis was used to calculate the significance differences between the means scores on test sub-domains and on all the test domains, as shown in table $(4,5)$.

Table 4

Multiple One-Way ANOVA analysis for the effect of teaching method on each skill

\begin{tabular}{|c|c|c|c|c|c|c|}
\hline & Writing Skill & $\begin{array}{l}\text { Total } \\
\text { Squares }\end{array}$ & dif & $\begin{array}{l}\text { Means } \\
\text { Squares }\end{array}$ & $\begin{array}{l}\mathrm{F} \\
\text { Value }\end{array}$ & Sig. \\
\hline \multirow{5}{*}{$\begin{array}{l}\text { Teaching } \\
\text { Method }\end{array}$} & Middle Hamza & 566.59 & 1 & 566.59 & 18.77 & 0.000 \\
\hline & Adding "if" (?th) to Adverbs & 101.55 & 1 & 101.55 & 10.80 & 0.001 \\
\hline & Dual Alef & 147.65 & 1 & 147.65 & 18.04 & 0.000 \\
\hline & $\begin{array}{l}\text { "An" (?n) for Accusative and "La" for } \\
\text { Denial, Joined or Separated }\end{array}$ & 182.62 & 1 & 182.62 & 18.36 & 0.000 \\
\hline & "L" of Imperative and "F" Added to it & 120.15 & 1 & 120.15 & 11.92 & 0.001 \\
\hline \multirow{5}{*}{ Error } & Middle Hamza & 2564.9 & 85 & 30.18 & & \\
\hline & Adding "if" (?th) to Adverbs & 738.67 & 85 & 9.39 & & \\
\hline & Dual Alef & 695.75 & 85 & 8.19 & & \\
\hline & $\begin{array}{l}\text { "An" (?n) for Accusative and "La" for } \\
\text { Denial, Joined or Separated, }\end{array}$ & 845.61 & 85 & 9.95 & & \\
\hline & "L" of Imperative and "F" Added to it & 856.96 & 85 & 10.08 & & \\
\hline \multirow{5}{*}{ Total } & Middle Hamza & 3131.6 & 86 & & & \\
\hline & Adding "if" (?th) to Adverbs & 900.23 & 86 & & & \\
\hline & Dual Alef & 843.40 & 86 & & & \\
\hline & $\begin{array}{l}\text { "An" (?n) for Accusative and "La" for } \\
\text { Denial, Joined or Separated }\end{array}$ & 1028.2 & 86 & & & \\
\hline & "L" of Imperative and "F" Added to it & 977.10 & 86 & & & \\
\hline
\end{tabular}

Table (4) shows that there are statistically significant differences $(\alpha=0.05)$ due to the teaching method on all written skills, in favour of the integrative method.

Table 5

One-Way ANOVA analysis based on teaching method on students' performance in the total writing test

\begin{tabular}{llllll}
\hline & Total Squares & dif & Means Squares & F Value & Sig. \\
\hline Among Groups & 4971.13 & 1 & 4971.13 & 25.03 & 0.00 \\
\hline Within Groups & 16875.49 & 85 & 198.54 & & \\
\hline Total & 21846.62 & 86 & & & \\
\hline
\end{tabular}

Table (5) shows that there are statistically significant differences $(\alpha=0.05)$ due to the teaching method, were $F$ value was $(25.03)$ with a statically significance $(\alpha=0.00)$, in favor of the integrative method. 
Results of the Second question: What is the effect of using the integrative method in teaching children literature to develop writhing skill at seven grad students due to gender?

Means score and standard deviation was calculated for experimental group performance for writing sub-skill and for the total test based on gender.

Table 6

Experimental group means score and standard deviation for each writing sub-skill and for the total skills based on gender

\begin{tabular}{|c|c|c|c|c|}
\hline Writing Skills & Gender & $\mathrm{M}$ & $\mathrm{SD}$ & No. \\
\hline \multirow{3}{*}{ Middle Hamza } & Male & 18.50 & 4.84 & 24 \\
\hline & Female & 22.69 & 5.10 & 22 \\
\hline & Total & 20.48 & 5.34 & 46 \\
\hline \multirow{3}{*}{ Adding "if" (?th) to Adverbs } & Male & 13.67 & 2.68 & 24 \\
\hline & Female & 15.73 & 1.98 & 22 \\
\hline & Total & 14.65 & 2.57 & 46 \\
\hline \multirow{3}{*}{ Dual Alef } & Male & 14.17 & 2.57 & 24 \\
\hline & Female & 15.91 & 2.27 & 22 \\
\hline & Total & 15.00 & 2.45 & 46 \\
\hline \multirow{3}{*}{$\begin{array}{l}\text { "An" (?n) for Accusative and } \\
\text { "La" for Denial, Joined or } \\
\text { Separated }\end{array}$} & Male & 14.00 & 2.21 & 24 \\
\hline & Female & 16.09 & 2.21 & 22 \\
\hline & Total & 15.00 & 2.24 & 46 \\
\hline \multirow{3}{*}{$\begin{array}{l}\text { "L" of Imperative and "F" } \\
\text { Added to it }\end{array}$} & Male & 14.08 & 2.86 & 24 \\
\hline & Female & 14.30 & 2.76 & 22 \\
\hline & Total & 14.17 & 4.83 & 46 \\
\hline \multirow{3}{*}{ Grand Total } & Male & 74.42 & 11.54 & 24 \\
\hline & Female & 85.73 & 11.54 & 24 \\
\hline & Total & 79.83 & 12.76 & 46 \\
\hline
\end{tabular}

Table (6) shows an apparent variance in the means score and the standard deviation of the experimental group on each writing sub-skill and on the total test based on gender.

It shows apparent variance in the means score and the standard deviation for experimental group performance consisting of seven grade students on each writing subskill and on the total test based on gender.

Multiple ANOVA analysis was used to calculate the significance differences on writing skill, and one-way ANOVA analysis was used to calculate the significance differences on the total writing test, as it shown in table $(7,8)$. 
Table 7

Multiple One-Way ANOVA analysis based on gender on each sub-skill of the total spelling test skills

\begin{tabular}{|c|c|c|c|c|c|c|}
\hline $\begin{array}{l}\text { Variance } \\
\text { Source }\end{array}$ & Skills & Total Squares & Dif & $\begin{array}{l}\text { Means } \\
\text { Squares }\end{array}$ & F Value & Sig. \\
\hline \multirow{5}{*}{$\begin{array}{l}\text { Hotelling } \\
\text { Method= } 0.344 \\
\mathrm{H}=0.031 \\
\mathbf{1}\end{array}$} & Middle Hamza & 196.39 & 1 & 196.39 & 7.69 & 0.007 \\
\hline & $\begin{array}{l}\text { Adding "if" (?th) to } \\
\text { Adverbs }\end{array}$ & 48.74 & 1 & 48.74 & 8.66 & 0.005 \\
\hline & Dual Alef & 34.85 & 1 & 34.85 & 5.92 & 0.019 \\
\hline & $\begin{array}{l}\text { "An" (?n) for Accusative } \\
\text { and "La" for Denial, } \\
\text { Joined or Separated }\end{array}$ & 50.18 & 1 & 50.18 & 10.05 & 0.003 \\
\hline & $\begin{array}{l}\text { "L" of Imperative and } \\
\text { "F" Added to it }\end{array}$ & 18.81 & 1 & 18.81 & 2.36 & 0.132 \\
\hline \multirow{5}{*}{ Error } & Middle Hamza & 1085.09 & 44 & 24.66 & & \\
\hline & $\begin{array}{l}\text { Adding "if" (?th) to } \\
\text { Adverbs }\end{array}$ & 247.70 & 44 & 5.63 & & \\
\hline & Dual Alef & 259.15 & 44 & 5.89 & & \\
\hline & $\begin{array}{l}\text { "An" (?n) for Accusative } \\
\text { and "La" for Denial, } \\
\text { Joined or Separated }\end{array}$ & 219.82 & 44 & 4.99 & & \\
\hline & $\begin{array}{l}\text { "L" of imperative and } \\
\text { "F" added to it }\end{array}$ & 350.92 & 44 & 7.98 & & \\
\hline \multirow{5}{*}{ Total } & Middle Hamza & 1281.45 & 45 & & & \\
\hline & $\begin{array}{l}\text { Adding "if" (?th) to } \\
\text { Adverbs }\end{array}$ & 296.44 & 45 & & & \\
\hline & Dual Alef & 294.00 & 45 & & & \\
\hline & $\begin{array}{l}\text { "An" (?n) for Accusative } \\
\text { and "La" for Denial, } \\
\text { Joined or Separated, }\end{array}$ & 270.00 & 45 & & & \\
\hline & $\begin{array}{l}\text { "L" of Imperative and } \\
\text { "F" Added to it }\end{array}$ & 369.74 & 45 & & & \\
\hline
\end{tabular}

Table (7) shows that there are statistically significant $(\alpha=0.05)$ due to gender in all skills except "L" of imperative and " $F$ " added to it, in favour of females.

Table 8

One-Way ANOVA analysis for the total performance for study sample in spelling test based on gender

\begin{tabular}{llllll}
\hline & Total Squares & dif & Means Squares & F Value & Sig. \\
\hline Among Groups & 1468.42 & 1 & 1468.41 & 11.03 & 0.002 \\
\hline Within Groups & 5858.19 & 44 & 133.14 & & \\
\hline Total & 7326.61 & 45 & & & \\
\hline
\end{tabular}

Table $(8)$ that there are statistical differences $(\alpha=0.05)$ due to gender, where $F$ value was (11.03) with statistical significance $(\alpha=0.002)$, in favour of females. 


\section{DISCUSSION}

First question: What is the effect of using an integrative method in teaching children's literature on the development of writing skill among seventh grade students?

The study found statistically significant differences due to the teaching method on all written skills, in favour of the integrative method. This result may be attributed to the fact that language learning and teaching should take an integrative form as scholars such as Sakhelashvili (2016) and Jubran (2017) have emphasized that when teaching a specific language skill, the other skills cannot be ignored since learning such skill needs that the learner rely on other language skills so as he can master the targeted skill.

Affirming this, Almuhairi (2019) suggested that learning Arabic is a difficult task for both students and teachers and this may be due to that such language is complicated, entails different symbols and that learners should master other skills so as they can learn a new skill. In the same line, Abd Hamid and Alkhawaldeh (2018) called teachers to use effective instructional method to teach students language skills since they are not easily mastered, which make it difficult for teachers and students alike face hardships in their effort.

Knowing that any given language consists of different skills, using integrative approach is an effective means of instruction as the learning material provided in this strategy aims to promote students writing skills by engaging them in real life activities that have a positive effect on their writing quality. Additionally, promoting students vocabulary (Reading), their oral expression (Speech), an active listening enables them to be more proficient writers. When the teacher works on giving students the chance to work on their language skills concurrently the benefits are enormous and this was evident in the results of this study.

In their research, Ibrahim and Al-Deleamy (2013) used integrative approach in teaching students different language skills and affirmed that when giving students rich experiences in learning the various language skills while targeting a specific one was a much effected instructional method for students in different grade levels. In the same line, Djakaridja and Ismail (2016) used integrative approach in teaching students reading comprehension and found that such an instructional method was very effective.

This result is consistent with the result reported by Alnassir (2011); indicating that the effectiveness of integrative approach lies in its employment of different language skills at the same time while working on promoting a certain one among students. As indicated by different schoolers (Abu Dahroj, 2016) and language teachers, language skills cannot be separated if the teacher wishes to achieve the highest level of a skill mastering among students. In the same line, both Abu Hamda and Al-Khawaldeh (2017) used integrative approach in teaching students Arabic skills and concluded that such a strategy is based on different assumptions; the most important is that teachers should provide students with rich reading experiences to facilitate their acquisition of the desired language skills. The integrative approach used in this study was well structured, highly organized and 
was developed based on a comprehensive review of previous literature (Bin Daymoon, Bin Sa'd \& Ja'far, 2018), thus, making use of every moment of the class to give students an invaluable opportunities to be exposed to learning experiences that can help them produce high quality writing products.

\section{Second question: What is the effect of using the integrative method in teaching children literature to develop writhing skill at seven grad students due to gender?}

The study found a statistical significant difference due to gender, in favour of females. This can be attributed to the fact that verbal intelligence among females is higher than males. In their study, Sukar and Ghanem (2011) indicated that females register higher levels of verbal intelligence than males. Since writing is one of language skills, then the greatest benefit that females have registered is consistent with the results of some previous studies, such as Murcy (2002) which mentioned that the level of language development and growth among females is higher than males due to some biological and psychological factors, the most important of which is that females show faster physical growth than males which give them the opportunity to take advantage of their verbal intelligence. Also, the speed of verbal growth of females gives them the opportunity to establish linguistic knowledge stock larger than males which make them in a better place to take advantage of the teaching strategies presented to them.

\section{CONCLUSION}

The study aimed to investigate the effect of child literature based integrative instructional program on promoting $7^{\text {th }}$ graders writing skills at Irbid governorate in Jordan. It was found that there were statistically significant differences in the means scores of writing skill posttest, in favor of the experimental group. It was also found statistically significant differences in the effect of using the integrative method in teaching children literature to develop writhing skill among seventh grad students due to gender, in favor of females.

\section{RECOMMENDATIONS}

Based on the results, the following recommendations are suggested:

- Calling language teachers to use integrative approaches when teaching different language skills as this instructional strategy has proven to be effective in the various language classes.

- Developing language skills curricula that take into consideration the use of various instructional programs when teaching language skills.

- Designing training programs targeting teachers to be able to effectively use integrative approaches in teaching as such an instructional program has proven to be effective in language classrooms.

- Calling teachers to write their lesson plans in a way conforming with using integrative approach while presenting learning content to students in language classrooms. 
- Future research may examine the effect of integrative approaches in developing other language skills such as reading and listening among other students populations.

\section{REFERENCES}

Abd Hamid, M., \& Alkhawaldeh, A. (2018). Impact of an instructional program based on collaborative learning using social networking site on improving Arabic writing skills among Malaysian non-Arabic speaking students. Dirasat, Educational Sciences, 45(4), $17-45$.

Abu Dahroj, E. (2016). The effectiveness of an integrated curriculum-based program in developing third graders writing skills in Gaza. Master Thesis, Islamic University of Gaza, Palestine.

Abu Hamda, S., \& Al-Khawaldeh, N. (2017). The effect of active learning in developing reading and writing skills for third grade students in Jordan. Al-Mishkat Journal for Humanities and Social Sciences, 4(2), 129-169.

Almosa, N. (2003). Methods: Curriculum and models for teaching Arabic language. Dar Alshorok for Publication and Distribution.

Almuhairi, A. (2019). The impact of instructional software in developing reading, writing and self-learning skills in reading and writing curriculum for the students of the University of Jordan. Arab Journal for Quality Assurance in Higher Education, 12(39), 63-84.

Alnassir, M. (2011). The effect of teaching reading and writing skills by integrated approach for Arabic subjects on development of this two skills for students of sixth grad elementary class on Qatif governorate in Kingdom of Saudi Arabia. Dirasat, Educational Sciences, 38, 1539-1550.

Alnooh, A. (2015). Investigating the impact of using an integrated approach to the teaching of writing skills amongst secondary students of English as a foreign language in Saudi Arabia. Master Thesis, University of Hull, England.

Aydin, B., Unver, M., Alan, B. \& Saglam, S. (2017). Combining the old and the new: Designing a curriculum based on the Taba model and the global scale of English. Journal of Learning and Linguistics, 13(1), 304-320.

Barakat, Z. (2006). An analytical study for examining common spelling mistakes by basic stage students at Tul Karem City, Palestine. Master Thesis, Al-Quds Open University, Palestine.

Bassal, S. (2005). The instructional aids and their effect on developing creative writing skills among first secondary school students. Master Thesis, Al Zaqazeeq University, Egypt.

Bin Daymoon, A., Bin Sa'd, M., \& Ja'far, T. (2018). The employment of documentary films in enhancing writing skills: A quasi experimental study of Arabic majoring 
students. Al-Quds Open University Journal for Educational \& Psychological Research \& Studies, 8(24), 110-121.

Dahrouj, E. (2016). The effectiveness of an integrated curriculum - based program in developing third graders writing skills in Gaza. Master Thesis, Islamic University of Gaza, Palestine.

Djakaridja, K. \& Ismail, M. (2016). Suggested educational applications for teaching Arabic in Arab schools in West Africa in light of the integrative methods. Language practices, 7(36), 63-104.

Erdogan, T. (2013). The effect of creative drama method on pre-service classroom teachers' writing skills and attitudes towards writing. Australian Journal of Teacher Education, 38(1), 45-63.

Graham, S., Berninger, V., \& Abbott, R. (2012). Are attitudes toward writing and reading separable constructs? A study with primary grade children. Reading \& Writing Quarterly, 28(1), 51-69.

Graham, S., Berninger, V., \& Abbott, R. (2012). Are attitudes toward writing and reading separable constructs? A study with primary grade children. Reading \& Writing Quarterly, 28(1), 51-69.

Ibrahim, A., \& Al-Deleamy, T. (2013). Teaching Arabic language in the integrative strategy between theory and practice: The problem and its importance. Journal of Education and Science, 20(1), 345-364.

Javed, M., Juan, W., \& Nazli, S. (2013). A Study of Students' Assessment in Writing Skills of the English Language. International Journal of Instruction, 6(2), 129- 144.

Jubran, S. (2017). A program based on the integration of product-process approach in teaching writing in Al-Balqa Applied University. Dirasat, Educational Sciences, 44(4), 361-367.

Kellogg, R. (2008). Training Writing Skills: A Cognitive Developmental Perspective. Journal of Writing Research, 1(1), 1-26.

Muhammad, A. (2018). The availability of the integrated approach skills in the primary teachers of Arabic through the improved curriculum. Journal of Education, 74(180), 75122.

Muradi, A. (2018). The reality of teaching writing skills in Indonesia: Problem and solutions. Arabiyat: Journal Pendidikan Bahasa Arab dan Kebahasaaraban, 5(1), 157 170 .

Murthy, P., \& Ram, R. (2015). Integrated approach to English language teaching in L2 classroom: A conceptual framework. Journal of English Language and Literature, 2(4), 101-104.

Rababeh, I., \& Abu Jamous, A. (2012). The effect of a critical reading instructional program in the development of critical reading, critical writing skills and creative of 
Jordanian tenth basic grade students. Al Najah Journal for Human Sciences, 26(5), $1028-1050$

Ryan, P., Glodji, T., Hobbs, B., Stragel, V., \& Williams, T. (2015). Navagating complexities: An integrative approach to English language teacher education. Issues in Interdisciplinary Studies, 33, 181-209.

Sakhelashvili, T. (2016). Teaching methods and integrative lesson. Multidisciplinary Academic Conference, prague, Czech Republic, December $9^{\text {th }}-10^{\text {th }}$.

The Jordanian Ministry of Education. (2006). General guidelines and specific outcomes for the English language. The English Language National Team, Jordan, MOE.

Sukar, H. \& Ghanem, H. (2011). Verbal intelligence among preparatory students. Journal of Educational and Psychological Researches, (31), 143-170. 